\title{
Novel Nonsense Mutation (p.Y113X) in the Human Growth Hormone Receptor Gene in a Brazilian Patient with Laron Syndrome
}

\author{
clinical case report
}

\author{
ERIK TROVÃo DINIZ \\ Alexander A. L. JoRge \\ IVO J. P. ARNHOLD \\ ArLAN L. ROSENBLOOM \\ FRANCISCO BANDEIRA
}

Divisão de Endocrinologia e Diabetes, Hospital Agamenon Magalhães, Sistema Único de

Saúde (SUS), Universidade de Pernambuco (ETD, FB), Recife, PE, Brasil; Unidade de Endocrinologia do Desenvolvimento, Laboratório de Hormônios e Genética Molecular LIM/42, Disciplina de Endocrinologia da Faculdade de Medicina da Universidade de São Paulo (FMUSP) (AALJ, IJPA), São Paulo, SP, Brasil; Departament of Pediatrics - University of

Florida College of Medicine, Children's Medical Services Center (ALR), Gainesville, FL, USA.

Received in 25/8/2008 Accepetd in $3 / 11 / 2008$
Background: To date, about sixty different mutations within $G H$ receptor (GHR) gene have been described in patients with GH insensitivity syndrome (GHI). In this report, we described a novel nonsense mutation of GHR. Methods: The patient was evaluated at the age of $6 \mathrm{yr}$, for short stature associated to clinical phenotype of GHI. GH, IGF-1, and GHBP levels were determined. The PCR products from exons $2-10$ were sequenced. Results: The patient had high GH $(26 \mu \mathrm{g} / \mathrm{L})$, low IGF-1 $(22.5 \mathrm{ng} / \mathrm{ml})$ and undetectable GHBP levels. The sequencing of GHR exon 5 disclosed adenine duplication at nucleotide 338 of GHR coding sequence (c.338dupA) in homozygous state. Conclusion: We described a novel mutation that causes a truncated GHR and a loss of receptor function due to the lack of amino acids comprising the transmembrane and intracellular regions of GHR protein, leading to GHI. (Arq Bras Endocrinol Metab 2008; 52/8:1264-1271)

Keywords: Growth hormone insensitivity; Somatotropin receptors; Genetics; Growth

\section{RESUMO}

Nova Mutação Nonsense (p.Y113X) no Gene do Receptor do Hormônio do Crescimento em um Paciente Brasileiro com Síndrome de Laron.

Introdução: Até o momento, aproximadamente 60 diferentes mutações envolvendo o gene do receptor do $\mathrm{GH}$ (GHR) foram descritas em pacientes com a síndrome de insensibilidade ao GH (GHI). Neste artigo, descrevemos uma nova mutação nonsense do GHR. Métodos: $O$ paciente foi avaliado aos 6 anos de idade para baixa estatura associada ao fenótipo clínico da GHI. Níveis de GH, IGF-1 e GHBP foram determinados. Os produtos de PCR dos éxons 2-10 foram seqüenciados. Resultados: $\mathrm{O}$ paciente apresentou níveis elevados de GH (26 $\mu \mathrm{g} / \mathrm{L})$, baixos de IGF-1 $(22.5 \mathrm{ng} / \mathrm{ml})$ e indetectáveis de GHBP. O seqüenciamento do éxon 5 do GHR revelou uma duplicação da adenina no nucleotídeo 338 da sequência de codificação do GHR (c.338dupA) em homozigose. Conclusão: Descrevemos uma nova mutação que causa um GHR truncado e uma perda da função do receptor devido à perda de aminoácidos compreendendo as regiões transmembrana e intracelular do receptor, levando a GHI. (Arq Bras Endocrinol Metab 2008; 52/8:1264-1271)

Descritores: Insensibilidade ao hormônio do crescimento; Receptores do hormônio do crescimento; Genética; Crescimento

\section{INTRODUCTION}

he Laron syndrome (LS) is a genetic disorder defined as the inability to respond to endogenous or exogenous GH with appropriate growth and metabolic effects. It is caused by defects in the GH receptors (GHR). Clinically, growth hormone insensitivity (GHI) is characterized by severe growth failure after birth, 
craniofacial disproportion, elevated serum $\mathrm{GH}$ and low IGF-I that failed to respond to GH (1-3).

LS is caused, in most cases, by a fully penetrant autosomal recessive mechanism leading to genetic defects along the GH-IGF axis, including the GHR. The GHR gene on the short arm of chromosome 5 includes 9 exons comprising 620 amino acid residues in its mature form. The GHR protein can be divided into the extracellular domain (encoded by exons 2-7), the transmembrane domain (encoded by exon 8 ), and the intracellular domain (encoded by exons 9 and 10) $(4,5)$.

The first genetic defect of the GHR described was a deletion of exons 5 and 6 which encode a large extracellular GH-binding domain. Since then, about sixty mutations of the GHR gene have been described (6).

Ethnic origin of reported cases is predominantly Middle Eastern, Mediterranean, South Asian and Ecuadorian. In Brazil twelve patients with the LS have been reported so far, including six children from Orobó (Pernambuco state) carrier of the E180 splice site mutation (7). Another case, also from Pernambuco (city of Recife), was described in 1997 (8) and, in this paper, a novel mutation in the exon 5 of GHR in this patient is described for the first time.

\section{SUBJECTS AND METHODS}

\section{Case report}

The patient was evaluated for short stature, soon after adoption. Birth length was $44 \mathrm{~cm}$ and weight $3 \mathrm{~kg}$. At the age of 6.5 years, his height was $77 \mathrm{~cm}$ [height standard deviation score (SDS) -8.0 ], weigh $9 \mathrm{~kg}$ [90\% of ideal body weight for height (IBW)] and bone age of 3 years.

When he was $10 \mathrm{yr} 9$ mo of age, he was reevaluated and measured $86 \mathrm{~cm}$ in height (height SDS -8.8 ) and weighed $12 \mathrm{~kg}(100 \% \mathrm{IBW})$. At 12 years of age his height was $87.8 \mathrm{~cm}$ (height SDS -8.4) and his weight $11.1 \mathrm{~kg}(89 \% \mathrm{IBW})$. Head circumference was $49.1 \mathrm{~cm}$, 25th percentile for his height (ie normal head circumference for 24 months).

He had facial asymmetry, prominent forehead, depressed nasal bridge, short vertical dimension of the face, microstomia and blue sclerae. There was severe dental crowding and caries of retained primary dentition. His voice was high pitched. There was limited elbow extension of approximately 5 degrees bilaterally. Stretched penile length was $4 \mathrm{~cm}$ (10th percentile for age 3 ) and the testes were $1 \mathrm{~mL}$ bilaterally.
After the diagnosis of GHI, he was treated with human recombinant IGF-I (Genentech, South San Francisco, CA) at a dosage of $100 \mu \mathrm{g} / \mathrm{kg} /$ body weight twice daily by subcutaneous injection. During the subsequent 6 months he grew $3.1 \mathrm{~cm}$ at the rate of $6 \mathrm{~cm} /$ year.

\section{Hormonal studies}

The GH was determined by quimioluminescence (Immulite-DPC 2000). The assay was calibrated against WHO IRP $80 / 505$ and recognized $22 \mathrm{kDa}$ GH isoform; interassay coefficient of variation was $4,6 \%$. The IGF- 1 and IGFBP-3 were measured using immunoradiometric assay (Immulite-DPC 2000) and interassay coefficient of variation were 3,9 e 4,8\%, respectively. The GHBP was determined by ligand-mediated immunofunctional assay (LIFA; Esoterix, Austin, TX, USA).

IGF-1 generation test involved daily injections of recombinant human $\mathrm{GH}(0,1 \mathrm{U} / \mathrm{kg}$ subcutaneously) for 4 days. Blood samples were drawn in the morning before the first injection and 12 hours after the last dose. IGF-1 increase $<15 \mu \mathrm{g} / \mathrm{L}$ was considered for the diagnosis of GHI.

\section{Molecular studies}

Genomic DNA was isolated from peripheral blood leucocytes from the patient and 50 normal height controls. We studied the GHR gene of the patient, amplifying exons 2-9 using specific intronic primers and exon 10 in three overlapping fragments to cover the entire coding region.

PCR was carried out in a $25-\mu \mathrm{l}$ mixed solution, containing 50-200 ng genomic DNA, $20 \mathrm{pmol} / \mathrm{L}$ each pair of primers, $0.2 \mathrm{mmol} / \mathrm{L}$ each of deoxy-ATP, -GTP, -CTP, -TTP, 1.5 to $4.0 \mathrm{mmol} \mathrm{MgCL}_{2}, 0.5 \mathrm{U}$ Taq DNA polymerase, $50 \mathrm{mmol} / \mathrm{l} \mathrm{KCl}, 10 \mathrm{mmol} / \mathrm{l}$ Tris- $\mathrm{HCl}(\mathrm{pH}$ 8.3) (Table 1). PCR involved initial denaturation step for $5 \mathrm{~min}$ at $95^{\circ} \mathrm{C}, 35$ cycles of denaturation for $1 \mathrm{~min}$ at $94{ }^{\circ} \mathrm{C}$, primer annealing for $1 \mathrm{~min}$ at $55 \mathrm{C}$, and primer extension for $1 \mathrm{~min}$ at $72 \mathrm{C}$, followed by a final extension step for $10 \mathrm{~min}$ at $72 \mathrm{C}$ in a thermal-cycler. PCR products were viewed after electrophoresis on $2 \%$ (wt/vol) agarose gel stained with ethidium bromide and photographed under UV light. PCR products from exons 2-10 were directly sequenced with dideoxy chain-termination method using a kit ABI PrismTM BigDye Terminator (Perkin Elmer, Foster City, CA, USA) and analysed by an autosequencer ABI Prism Genetic Analyser 3100 automatic DNA sequencer (Perkin Elmer). Exon 5 of 50 control samples were amplified by PCR and directly sequenced. 
Table 1. Primer pairs to amplify the GHR coding sequence, sizes of PCR products and final MgCl2 concentration for PCR reaction.

\begin{tabular}{|c|c|c|c|}
\hline Exon & Primer & $\begin{array}{l}\text { PCR product } \\
\text { (bp) }\end{array}$ & $\left(\mathrm{MgCl}_{2}\right)$ \\
\hline \multirow[t]{2}{*}{2} & Sense: 5’ TTTCATGATAATGGTCTGCT 3' & 193 & $1.5 \mathrm{mM}$ \\
\hline & Antisense: 5' GAATACAGTTCAGTGTTGTTT 3' & & \\
\hline \multirow[t]{2}{*}{3} & Sense: 5' GATGGACTAGATGGTTTTGCCTTCCTCTTTCTGTTTCAG 3' & 100 & $1.5 \mathrm{mM}$ \\
\hline & Antisense: 5' GGATAGTAGCTTAATTACAC 3' & & \\
\hline \multirow[t]{2}{*}{4} & Sense: 5' AGGATCACATATGACTCACC 3' & 231 & $2.5 \mathrm{mM}$ \\
\hline & Antisense: 5' AGGAAAATCAGAAAGGCATG 3' & & \\
\hline \multirow[t]{2}{*}{5} & Sense: 5' ACTTAAGCTACAACATGATT 3' & 274 & $4.0 \mathrm{mM}$ \\
\hline & Antisense: 5' GCTTCCCCATTTATTTAGT 3' & & \\
\hline \multirow[t]{2}{*}{6} & Sense: 5' ATTGTGTCTGTCTGTGTACTAATG 3' & 247 & $1.5 \mathrm{mM}$ \\
\hline & Antisense: 5' ATAGAAAGAAAAGTCAAAGTGTAAG 3' & & \\
\hline \multirow[t]{2}{*}{7} & Sense: 5'TAGTGTTCATTGGCATTGAG 3' & 328 & $3.0 \mathrm{mM}$ \\
\hline & Antisense: 5' ACAAAAGCCAGGTTAGCTAC 3' & & \\
\hline \multirow[t]{2}{*}{8} & Sense: 5' GAAACTGTGCTTCAACTAGTC 3' & 205 & $4.0 \mathrm{mM}$ \\
\hline & Antisense: 5' GGTCTAACACAACTGGTACA 3' & & \\
\hline \multirow[t]{2}{*}{9} & Sense: 5' GCTATAATTGAGAATATGTAG 3' & 204 & $1.5 \mathrm{mM}$ \\
\hline & Antisense: 5' CATATGACAGGAGTCTTCAGGTG 3' & & \\
\hline \multirow[t]{4}{*}{10} & Sense: 5' GAGTTTCTTTTCATAGATCTTCATTTTC 3' & 1.150 & $1.5 \mathrm{mM}$ \\
\hline & Antisense: 5' GGTTTAAACATTGTTTTGGC 3' & & \\
\hline & A*: 5' GTGCTCAGCCACAGAGGTT 3' & & \\
\hline & B*: 5' CCAGCAGGTAGTGTGGTCCT 3' & & \\
\hline
\end{tabular}

* primers used only for sequence.

\section{RESULTS}

\section{Hormonal results}

During insulin-induced hypoglycemia stimulation test, GH rose from a high baseline of $26 \mu \mathrm{g} / \mathrm{L}$ to $52 \mu \mathrm{g} / \mathrm{L}$ at 45 minutes. IGF-I level was low at $22.5 \mathrm{ng} / \mathrm{ml}$ (normal for age: $80-650 \mathrm{ng} / \mathrm{ml}$ ) and the IGFBP-3 level was also low at $100 \mathrm{ng} / \mathrm{ml}$ (normal for age: 2000-6000 $\mathrm{ng} / \mathrm{ml})$. After exogenous $\mathrm{GH}$ injection $(0.1 \mathrm{U} / \mathrm{kg} /$ day) for 4 days, the serum IGF-I was $24 \mathrm{ng} / \mathrm{dl}$.

At the age of 12 years, he was evaluated at the University of North Carolina to entry into a treatment program with recombinant IGF-I injections and was found to have an IGF-I level in serum of $<10 \mathrm{ng} / \mathrm{ml}$, and a $\mathrm{GH}$ level of $22 \mu \mathrm{g} / \mathrm{L}$. After 4 days of GH injections $(0.1 \mathrm{U} / \mathrm{kg} /$ day $)$, there was no change in IGF-I serum concentration. The serum concentration of GH-bind- ing protein $(\mathrm{GHBP})$ was undetectable $(<140 \mathrm{pmol} / \mathrm{l}$; normal for ages 10-15 yr, 431-1892 pmol/l).

\section{Molecular results}

Direct sequence of GHR exon 5 (DNA reference sequence: NM_000163) disclosed an adenine duplication at nucleotide 338 of the GHR coding sequence (c.338dupA) and was observed in homozygous state in the patient's genomic DNA. This allelic variant was not found in 100 alleles from the control group and causes a nonsense mutation through the conversion of tyrosine (TAC) into a premature termination signal (TAA) (p. Y113X). This stop codon occurs in the extracellular domain and produces a truncated GHR that would be unable to exhibit receptor function, due to the lack of 525 amino acids comprising the transmembrane and intracellular regions of GHR protein. 


\section{DISCUSSION}

Growth hormone insensitivity (GHI) is a rare disorder and 12 Brazilian patients have been reported to date (7), including the present patient (8). All these patients presented with the typical clinical features of LS with elevated serum GH, low IGF-I which failed to respond to $\mathrm{GH}$, and low GHBP.

Among Brazilian GHI patients, molecular studies were conducted in 6 cases, and all of them presented homozygous mutations in GHR gene. The first two GHI cases reported from Brazil were homozygous for a substitution of $\mathrm{T}$ for $\mathrm{G}$ at the -1 position of the 3 ' splice consensus sequence of intron 6 (c.619-1 G>C) $(9,10)$. Another patient carried a homozygous mutation, replacing serine by isoleucine in codon 244 of exon 7 (p.S244I) (11). The last six patients described in Brazil were also from Pernambuco and carried a homozygous replacement of guanine by adenine in codon 198 of exon 6 (c.594 A>G), creating an abnormal splice site deleting 8 amino acids from the extracellular domain of GHR (p.V199_M206del) (7). To date, this is the most common mutation present in
Brazil, as well as in the world. The mutation in codon 198, also known as E180Splice mutation, has been described in Ecuadorian patients and two Israeli patients of Moroccan descent $(12,13)$.

Finally, in the present study, we describe a novel nonsense GHR mutation in homozygous state, adenine duplication at nucleotide 338 (c.338dupA). This nucleotide alteration causes a premature termination signal at condon 113 (p.Yl13X), predicting a truncated GHR that would be unable to exhibit receptor function due to the lack of amino acids comprising the transmembrane and intracellular regions of GHR protein. This molecular finding is in accord with undetectable levels of GHBP observed in our patient. GHBP is a product of proteolytic cleavage of the extracellular domain of GHR and is typically absent or present at low levels in patients with $\mathrm{GHI}$, reflecting failure of $\mathrm{GH}$ receptor synthesis (14).

To date, approximately 60 GHR defects have been described, such as gross deletions, missense, nonsense, frameshift, and splice site mutations. Fourteen nonsense mutations in GHR were described (Table 2), being 2 of them located in exon $5(22,23)$.

Table 2A. Standard and colloquial nomenclature for GHR mutations (Gross Deletion and Nonsense mutations).

\begin{tabular}{|c|c|c|c|c|c|}
\hline Type of Mutation & $\begin{array}{c}\text { DNA sequence } \\
\text { change* }^{*}\end{array}$ & $\begin{array}{l}\text { Site of } \\
\text { mutation }\end{array}$ & $\begin{array}{l}\text { Amino acid } \\
\text { change }\end{array}$ & $\begin{array}{c}\text { Colloquial } \\
\text { nomenclature }\end{array}$ & Reference \\
\hline \multicolumn{6}{|l|}{ Deletion } \\
\hline & $\sim 1.2 \mathrm{~kb}$ deletion & $\begin{array}{l}\text { Partial Exon } 5 \\
\text { deletion }\end{array}$ & & & (15) \\
\hline & $\sim 4 \mathrm{~kb}$ deletion & Exon 5 & & & (16) \\
\hline & $19 \mathrm{~kb}$ deletion & Exon 5-6 & & & (17) \\
\hline & del(5) pl1-p13.1 & Exon 4-10 & & & (18) \\
\hline \multicolumn{6}{|l|}{ Nonsense } \\
\hline & c. $12 \mathrm{G}>\mathrm{A}$ & Exon 2 & p.W4X & W15X & (19) \\
\hline & c. $101 \mathrm{G}>\mathrm{A}$ & Exon 3 & p.W34X & W16X & (20) \\
\hline & c. 168 C>A & Exon 4 & p.C56X & C38X & (21) \\
\hline & C.181 C>T & Exon 4 & p.R61X & R43X & (21) \\
\hline & c. $247 \mathrm{C}>\mathrm{T}$ & Exon 4 & p.Q83X & Q65X & (22) \\
\hline & c.293 G>A & Exon 5 & p.W98X & W80X & (22) \\
\hline & c. 303 C>A & Exon 5 & p.C101X & C83X & (23) \\
\hline & c.338 dupA & Exon 5 & p.Y113X & Y97X & $\#$ \\
\hline & c. $476 \mathrm{~T}>\mathrm{A}$ & Exon 6 & P.L159X & L141X & (19) \\
\hline & c. $524 \mathrm{G}>\mathrm{A}$ & Exon 6 & p.W175X & W157X & (22) \\
\hline & $c .601 \mathrm{G}>\mathrm{T}$ & Exon 6 & p.E201X & E183X & (13) \\
\hline & c.703 C>T & Exon 7 & p.R235X & R217X & (24) \\
\hline & c.724 G>T & Exon 7 & p.E242X & E224X & (25) \\
\hline & c.744 delT & Exon 7 & p.Y248X & 230delT & (26) \\
\hline
\end{tabular}


Table 2B. Standard and colloquial nomenclature for GHR mutations (Frameshift and splice site mutations).

\begin{tabular}{|c|c|c|c|c|c|}
\hline \multicolumn{6}{|c|}{ Frameshift } \\
\hline & c.162delC & Exon 4 & p.K55fsX79 & 162delC & (22) \\
\hline & c.192_193delTT & Exon 4 & p.S65fsX70 & 46delTT & (9) \\
\hline & c.421_422dupTT & Exon 5 & P.L143fs 147 & 422insTT & (6) \\
\hline & c.743_744delAT & Exon 7 & p.Y248fs259 & 230 del AT & (9) \\
\hline & c.889_911del & Exon 9 & p.1297fs299 & $889-911 \mathrm{del}$ & (27) \\
\hline & c.981delC & Exon 10 & p.1328fs348 & 981delC & $(25)$ \\
\hline & c.1324_1345del & Exon 10 & p.A442fs 478 & GHR(1-499) & (28) \\
\hline & c.1734delG & Exon 10 & p.R578fs600 & 1776 del G & (23) \\
\hline \multicolumn{6}{|l|}{ Splice } \\
\hline & c.594 A>G & Exon 6 & p.V199_M206del & E180Splice & (29) \\
\hline & c.723 C>T & Exon 7 & & G236Splice & $(22,30)$ \\
\hline & c. 875 G>C & Exon 8 & P.R292T & R274T & (31) \\
\hline & c. $70+1 G>A$ & Intron 2 & & $70+1 G>A$ & (22) \\
\hline & c. $266+1 \mathrm{G}>\mathrm{A}$ & Intron 4 & & $71+1 G>A$ & (9) \\
\hline & c.440-1 G>C & Intron 5 & & IVS5 -1 G>C & (24) \\
\hline & c. $618+1.8 \mathrm{~kb} A>G$ & Intron 6 & & $\psi 6$ & (32) \\
\hline & c.619-1 G>T & Intron 6 & & $189-1 G>T$ & (9) \\
\hline & c.619-1 G>C & Intron 6 & & $189-1 G>C$ & (33) \\
\hline & $c .619-25 \mathrm{~A}>\mathrm{G}$ & Intron 6 & & IVS $6-25 \mathrm{~A}>\mathrm{G}$ & (29) \\
\hline & c.785-1 G>T & Intron 7 & & 785-1 G>T & (34) \\
\hline & c.876-1 C>G & Intron 8 & & GHR(1-277) & (35) \\
\hline & $c .945+1 \mathrm{G}>\mathrm{A}$ & Intron 9 & & GHR(1-277) & (36) \\
\hline
\end{tabular}

The description of GHR mutations started several years before any mutation nomenclature recommendations were proposed. Therefore, published and commonly used designations for many GHR mutations have been at variance with the evolving standard nomenclature guidelines (43). In Table 1, we reviewed all GHR mutations and disclosed the standard nomenclature and colloquial nomenclature side by side. Nucleotide numbering is based on cDNA reference sequence (NM_000163) and amino acid numbering is based on GHR protein reference (NP_000154), being the translation initiator Methionine numbered as +1 codon, in contrast to the colloquial notations that numbered the ATG initiation codon as -18 .

GHR mutations are concentrated in extracellular domain, mainly in exons 4, 5, 6 and 7; whereas mutations in the exons 8,9 and 10 are rare (Table 1 ). Although there are rare cases of autosomal dominant inheritance, the majority of cases of GHI are caused by an autosomal recessive mechanism or exhibit compound heterozygous defects. Most cases are associated with parental consanguinity $(4,14,44)$, but such data are not available for this patient. 
Table 2C. Standard and colloquial nomenclature for GHR mutations (Misense mutation and others).

\begin{tabular}{|c|c|c|c|c|c|}
\hline \multicolumn{6}{|l|}{ Missense } \\
\hline & C. $1 \mathrm{~A}>\mathrm{T}$ & Exon 2 & p.0? & M-18L & (37) \\
\hline & c. $166 \mathrm{~T}>\mathrm{A}$ & Exon 4 & p.C56S & C38S & (22) \\
\hline & c. 173 C>T & Exon 4 & p.S58L & S4OL & (22) \\
\hline & c. $148 \mathrm{G}>\mathrm{A}$ & Exon 4 & p.E60K & E42K & (38) \\
\hline & c.202 T>C & Exon 4 & p.W68R & W50R & (22) \\
\hline & $c .266 G>A$ & Exon 4 & P.R89K & R71K & (24) \\
\hline & c.310 T>G & Exon 5 & p.Y104D & Y86D & (26) \\
\hline & c.335 G>C & Exon 5 & p.C112S & C94S & $(4)$ \\
\hline & c.341 T>C & Exon 5 & p.F114S & F96S & (39) \\
\hline & c. $428 \mathrm{~T}>\mathrm{C}$ & Exon 5 & p.V143A & $\mathrm{V} 125 \mathrm{~A}$ & (24) \\
\hline & $c .446 \mathrm{C}>\mathrm{A}$ & Exon 6 & p.P149Q & P131Q & (40) \\
\hline & c. $485 \mathrm{~T}>\mathrm{A}$ & Exon 6 & p.V162D & V144D & (24) \\
\hline & $c .504 \mathrm{~T}>\mathrm{G}$ & Exon 6 & p.H168Q & H150Q & (4) \\
\hline & $c .508 \mathrm{G}>\mathrm{C}$ & Exon 6 & p.D170H & $\mathrm{D} 152 \mathrm{H}$ & (41) \\
\hline & c.512 T>C & Exon 6 & p.l171T & I153T & (27) \\
\hline & C. $515 A>C$ & Exon 6 & P.Q172P & Q154P & (27) \\
\hline & c. $518 \mathrm{~T}>\mathrm{G}$ & Exon 6 & p.V173G & V155G & (27) \\
\hline & $c .535 \mathrm{C}>\mathrm{T}$ & Exon 6 & P.R179C & R161C & (24) \\
\hline & c. $685 C>G$ & Exon 7 & p.R229G & R211G & (24) \\
\hline & $c .731 \mathrm{G}>\mathrm{T}$ & Exon 7 & p.S244l & S226I & (11) \\
\hline & c. $677 \mathrm{~A}>\mathrm{G}$ & Exon 7 & p.Y226C & Y208C & (42) \\
\hline & $c .784 G>A$ & Exon 7 & p.D262N & $\mathrm{D} 244 \mathrm{~N}$ & (42) \\
\hline
\end{tabular}

* Nucleotide numbering is based on DNA reference sequence NM_000163. Number nucleotides and name mutations or variants, respectively, according to the standard nomenclature recommendations (http://www.HGVS.org/mutnomen/).

Rarely, GHI may also result from mutations in signal transducer and activator of transcription $5 \mathrm{~B}$ gene (STAT5b; OMIM: 604260), the main component of the GH signaling pathway (5). STAT5b also plays an important role in signaling within immune cells, thus clinical immunodeficiency is common in patients with STAT5b deficiency, although is not an obligatory phenomenon $(4,45,46)$.

In conclusion, we expand the repertoire of GHR mutations describing the novel mutation (c.338dupA; p.Y113X) in a Brazilian GHI patient.
Acknowledgments: This article received support from the Fun dação de Apoio à Pesquisa do Estado de São Paulo (FAPESP) Projeto Temático 05/04726-0 and the Conselho Nacional de Desenvolvimento Científico e Tecnológico $(\mathrm{CNPq}): 307951 / 06-5$ to AALJ and 300938/06-3 to I.J.P.A. No potencial conflict of interest relevant to this article was reported.

\section{REFERENCES}

1. Laron Z. Laron syndrome (primary growth hormone resistance or insensitivity): the personal experience 1958-2003. J Clin Endocrinol Metab. 2004;89(3):1031-44. 
2. Laron Z, Pertzelan A, Mannheimer S. Genetic pituitary dwarfism with high serum concentration of growth hormone - a new inborn error of metabolism? Isr J Med Sci. 1966;2:152.

3. Woods K. Genetic defects of the growth-hormone-IGF axis associated with growth hormone insensitivity. Endocr Dev. 2007;11:6-15.

4. Fang P, Riedl S, Amselem S, Pratt KL, Little BM, Haeusler G, et al. Primary growth hormone $(\mathrm{GH})$ insensitivity and insulin-like growth factor deficiency caused by novel compound heterozygous mutations of the $\mathrm{GH}$ receptor gene: genetic and functional studies of simple and compound heterozygous states. $J$ Clin Endocrinol Metab 2007;92:2223-31.

5. Rosenbloom AL. Growth hormone insensitivity. In: Bandeira F, Graf H, Griz L, Faria M, Lazaretti-Castro M, editors. Endocrinologia Básica e Diabetes. 2. Ed. Rio de Janeiro: Medbook (in press).

6. Gennero I, Edouard T, Rashad M, Bieth E, Conte-Aurio F, Marin F, Tauber $\mathrm{M}$, et al. Identification of a novel mutation in the human growth hormone receptor gene (GHR) in a patient with Laron syndrome. J Pediatr Endocrinol Metab. 2007;20(7):825-31.

7. Jorge AA, Menezes Filho HC, Lins TS, Guedes DR, Damiani D, Setian N,et al. Founder effect of E180splice mutation in growth hormone receptor gene (GHR) identified in Brazilian patients with GH insensitivity. Arq Bras Endocrinol Metabol. 2005; 49(3):384-9.

8. Bandeira F, Camargo K, Caldas G, Rosenbloom AL, Stabler B, Underwood LE. Primary growth hormone insensitivity: case report. Arq Bras Endocrinol Metab. 1997;41:198-200.

9. Berg MA, Argente J, Chernausek S, Gracia R, Guevara-Aguirre J, Hopp $M$ at al. Diverse growth hormone receptor gene mutations in Laron syndrome. Am J Hum Genet. 1993;52(5):998-1005.

10. Saldanha PH, Toledo SP. Familial dwarfism with high IR-GH: report of two affected sibs with genetic and epidemiologic considerations. Hum Genet. 1981;59(4):367-72.

11. Jorge AA, Souza SC, Arnhold IJ, Mendonca BB The first homozygous mutation (S226I) in the highly-conserved WSXWSlike motif of the $\mathrm{GH}$ receptor causing Laron syndrome: supression of GH secretion by GnRH analogue therapy not restored by dihydrotestosterone administration. Clin Endocrinol (Oxf). 2004;60(1):36-40.

12. Berg MA, Guevara-Aguirre J, Rosenbloom AL, Rosenfeld RG, Francke $U$ Mutation creating a new splice site in the growth hormone receptor genes of 37 Ecuadorean patients with Laron syndrome. Hum Mutat. 1992;1(1):24-32.

13. Berg MA, Peoples R, Pérez-Jurado L, Guevara-Aguirre J, Rosenbloom AL, Laron Z, et al. Receptor mutations and haplotypes in growth hormone receptor deficiency: a global survey and identification of the Ecuadorean E180splice mutation in an oriental Jewish patient Acta Paediatr Suppl. 1994;399:112-4.

14. Rosenfeld RG, Rosenblom AL, Guevara-Aguirre J. Growth hormone $(\mathrm{GH})$ insensitivity due to primary $\mathrm{GH}$ receptor deficiency. Endocr Rev. 1994;15:369.

15. Gastier JM, Berg MA, Vesterhus P, Reiter EO, Francke U. Diverse deletions in the growth hormone receptor gene cause growth hormone insensitivity syndrome. Hum Mutat. 2000;16 (4):323-33.

16. Besson A, Salemi S, Eblé A, Joncourt F, Gallati S, Jorge AA, Mullis PE. Primary GH insensitivity '(Laron syndrome) caused by a novel $4 \mathrm{~kb}$ deletion encompassing exon 5 of the $\mathrm{GH}$ receptor gene: effect of intermittent long-term treatment with recombinant human IGF-I. Eur J Endocrinol. 2004;150(5):635-42.

17. Godowski PJ, Leung DW, Meacham LR, Galgani JP, Hellmiss $\mathrm{R}$, Keret $\mathrm{R}$, et al. Characterization of the human growth hormo- ne receptor gene and demonstration of a partial gene deletion in two patients with Laron- type dwarfism. Proc Natl Acad Sci U S A. 1989;86:8083-7.

18. Yamamoto H, Kouhara H, lida K, Chihara K, Kasayama S. A novel growth hormone receptor gene deletion mutation in a patient with primary growth hormone insensitivity syndrome (Laron syndrome). Growth Horm IGF Res. 2008;18(2):136-42.

19. Shevah O, Borrelli $P$, Rubinstein M, Laron Z. Identification of two novel mutations in the human growth hormone receptor gene. J Endocrinol Invest. 2003;26:604-8.

20. Pantel J, Grulich-Henn J, Bettendorf M, Strasburger CJ, Heinrich $\mathrm{U}$, Amselem $\mathrm{S}$. Heterozygous nonsense mutation in exon 3 of the growth hormone receptor (GHR) in severe $\mathrm{GH}$ insensitivity (Laron syndrome) and the issue of the origin and function of the GHRd3 isoform. J Clin Endocrinol Metab. 2003;88:1705-10.

21. Amselem S, Sobrier ML, Duquesnoy P, Rappaport R, PostelVinay MC, Gourmelen M, et al. Recurrent nonsense mutations in the growth hormone receptor from patients with Laron dwarfism. J Clin Invest. 1991;87:1098-102.

22. Sobrier ML, Dastot F, Duquesnoy P, Kandemir N, Yordam N, Goossens M, Amselem S. Nine novel growth hormone receptor gene mutations in patients with Laron syndrome. J Clin Endocrinol Metab. 1997;82:435-7.

23. Tiulpakov A, Rubtsov P, Dedov I, Peterkova V, Bezlepkina O, Chrousos GP, Hochberg Z. A novel C-terminal growth hormone receptor (GHR) mutation results in impaired GHR-STAT5 but normal STAT-3 signaling. J Clin Endocrinol Metab. 2005;90:542-7.

24. Amselem S, Duquesnoy P, Duriez B, Dastot F, Sobrier ML, Valleix S, Goossens M. Spectrum of growth hormone receptor mutations and associated haplotypes in Laron syndrome. Hum Mol Genet. 1993;2:355-9.

25. Kaji H, Nose O, Tajiri H, Takahashi Y, lida K, Takahashi T, et al. Novel compound heterozygous mutations of growth hormone $(\mathrm{GH})$ receptor gene in a patient with $\mathrm{GH}$ insensitivity syndrome. J Clin Endocrinol Metab. 1997;82:3705-9.

26. Shevah O, Rubinstein M, Laron Z. Molecular defects of the growth hormone receptor gene, including a new mutation, in Laron syndrome patients in Israel: relationship between defects and ethnic groups. Isr Med Assoc J. 2004;6(10):630-3.

27. Wojcik J, Berg MA, Esposito N, Geffner ME, Sakati N, Reiter $E O$, et al. Four contiguous amino acid substitutions, identified in patients with Laron syndrome, differently affect the binding affinity and intracellular trafficking of the growth hormone receptor. J Clin Endocrinol Metab. 1998;83:4481-9.

28. Milward A, Metherell L, Maamra M, Barahona MJ, Wilkinson IR, Camacho-Hubner C, et al. Growth hormone $(G H)$ insensitivity syndrome due to a $\mathrm{GH}$ receptor truncated after Box1, resulting in isolated failure of STAT 5 signal transduction. J Clin Endocrinol Metab. 2004;89:1259-66.

29. Berg MA, Guevara-Aguirre J, Rosenbloom AL, Rosenfeld RG, Francke $U$. Mutation creating a new splice site in the growth hormone receptor genes of 37 Ecuadorean patients with Laron syndrome. Hum Mutat. 1992; 1:24-32.

30. Baumbach L, Schiavi A, Bartlett R, Perera E, Day J, Brown MR, et al. Clinical, biochemical, and molecular investigations of a genetic isolate of growth hormone insensitivity (Laron's syndrome). J Clin Endocrinol Metab. 1997;82:444-51.

31. Woods KA, Fraser NC, Postel-Vinay MC, Savage MO, Clark AJL. A homozygous splice site mutation affecting the intracellular domain of the growth hormone $(\mathrm{GH})$ receptor resul- 
ting in Laron syndrome with elevated $\mathrm{GH}$-binding protein. J Clin Endocrinol Metab. 1996;81:1686-90.

32. Metherell LA, Akker SA, Munroe PB, Rose SJ, Caulfield M, Savage $\mathrm{MO}$, et al. Pseudoexon activation as a novel mechanism for disease resulting in atypical growth-hormone insensitivity. Am J Hum Genet. 2001;69:641-6.

33. Woods KA, Clark AJ, Amselem S, Savage MO. Relationship between phenotype and genotype in growth hormone insensitivity syndrome. Acta Paediatr Suppl. 1999;88(428):158-62.

34. Silbergeld A, Dastot F, Klinger B, Kanety H, Eshet R, Amselem S, et al. Intronic mutation in the growth hormone $(\mathrm{GH})$ receptor gene from a girl with Laron syndrome and extremely high serum GH binding protein: extended phenotypic study in a very large pedigree. J Pediatr Endocrinol Metab. 1997;10:265-74.

35. Ayling RM, Ross RJ, Towner P, Von Laue S, Finidori J, Moutoussamy $\mathrm{S}$, et al. New growth hormone receptor exon 9 mutation causes genetic short stature. Acta Paediatr Suppl. 1999;88:168-172; discussion 173.

36. Laron Z, Klinger B, Eshet $\mathrm{R}$, Kaneti $\mathrm{H}$, Karasik A, Silbergeld A. Laron syndrome due to a postreceptor defect: response to IGF-I treatment. Isr J Med Sci. 1993;29:757-63.

37. Quinteiro C, Castro-Feijoo L, Loidi L, Barreiro J, de la Fuente M, Dominguez F, Pombo M. 2002 Novel mutation involving the translation initiation codon of the growth hormone receptor gene (GHR) in a patient with Laron syndrome. J Pediatr Endocrinol Metab. 2002;15:1041-5.

38. Chen $X$, Song F, Dai $Y$, Bao $X$, Jin $Y$. A novel mutation of the growth hormone receptor gene (GHR) in a Chinese girl with Laron syndrome. J Pediatr Endocrinol Metab. 2003;16:1183-9.

39. Amselem S, Duquesnoy P, Attree O, Novelli G, Bousnina S, Postel-Vinay MC, et al. Laron dwarfism and mutations of the growth hormone-receptor gene. N Engl J Med. 1989;321:989-95.

40. Walker JL, Crock PA, Behncken SN, Rowlinson SW, Nicholson LM, Boulton TJ, Waters MJ. A novel mutation affecting the interdomain link region of the growth hormone receptor in a Vietnamese girl, and response to long-term treatment with recombinant human insulin-like growth factor-I and luteinizing hormone-releasing hormone analogue. J Clin Endocrinol Metab. 1998;83:2554-61.

41. Duquesnoy $P$, Sobrier ML, Duriez B, Dastot $F$, Buchanan $C R$, Savage MO, et al. A single amino acid substitution in the exoplasmic domain of the human growth hormone $(\mathrm{GH})$ receptor confers familial GH resistance (Laron syndrome) with positive $\mathrm{GH}$-binding activity by abolishing receptor homodimerization. Embo J. 1994;13:1386-95.

42. Enberg $B$, Luthman $H$, Segnestam K, Ritzen EM, Sundstrom $M$, Norstedt G. Characterisation of novel missense mutations in the $\mathrm{GH}$ receptor gene causing severe growth retardation. Eur J Endocrinol. 2000;143:71-6.

43. den Dunnen J, Antonarakis S. Nomenclature for the description of human sequence variations. Hum Mut. 2000;15:7-12.

44. Rosenbloom AL, Bandeira F. Primary growth hormone insensitivity syndrome: a review. Arq Bras Endocrinol Metab. 1997;41:155-62.

45. Kofoed EM, Hwa V, Little B, Woods KA, Buckway CK, Tsubaki $\mathrm{J}$, et al. Growth hormone insensitivity associated with a STAT5b mutation. N Engl J Med. 2003;349:1139-47.

46. Hwa V, Little B, Adiyaman P, Kofoed EM, Pratt KL, Ocal G, et al. Severe growth hormone insensitivity resulting from total absence of signal transducer and activator of transcription $5 \mathrm{~b} . \mathrm{J}$ Clin Endocrinol Metab. 2005;90:4260-6.

\section{Correspondence to:}

Erik Trovão Diniz

Rua Des. Gois Cavalcanti, 100, apt 205, Parnamirim

52060-140 Recife PE

E-mail: erik_td@hotmail.com 